\title{
Employee Participation by Codetermination, Labor Law, and Collective Bargaining
}

\author{
Hans G. Nutzinger
}

\begin{abstract}
Employee participation in the Federal Republic of Germany is mainly effected by legal and/or contractual limitations of managerial rights via codetermination, collective bargaining, and labor law. While these forms of participation are often perceived as a restriction to managerial discretion, this must not necessarily be so.

For different reasons, existing empirical evaluations do not provide a clear answer to the question whether there are overall efficiency losses both at the firm and the economy level due to those restrictions. There are many possible reasons for this state of affairs: first, the existing evaluations do not meet the standard of modern empirical research and hence fail to deliver clear results. Second, as codetermination is restricted to special sectors and special categories of enterprises, competition with non-restricted firms may hinder the realization of otherwise unavoidable negative consequences. Third, there are some positive consequences (e.g. in terms of cooperation and trust) connected with codetermination which may compensate for some other negative implications. Fourth, as employee participation increases job satisfaction, the room for managerial action may even be increased.

There is a basic methodological problem involved in any attempt at measuring the implications of employee participation: its influence is mediated by the way how management can cope with both the chances and limitations due to codetermination. This might help to explain why managerial evaluation of codetermination in Germany seems to be rather ambivalent: the diverging views may heavily depend upon the specific situation in different branches and firms. It is difficult, if not impossible, to judge $a$ priori whether more cooperative or more conflict-oriented patterns of interaction between management and employee representatives will evolve and persist. From an economic viewpoint, those forms of employee participation are to be preferred which are more flexible and hence easier adaptable to changed economic conditions. Hence, agreements at decentralized levels (such as works agreements) are to be preferred to more general and rigid rules as they are often provided by labor law.
\end{abstract}

\section{Introduction}

Due to particular historical conditions (cf. Muszynski 1975, Teuteberg 1961), employee participation in the Federal Republic of Germany has mainly taken the form of legal 
and/or contractual limitations of managerial rights via the following three sets of regulations:

- codetermination (including works constitution), as legally defined mainly by the Codetermination Law of 1951 in the mining and iron and steel producing industry, the Works Constitution Law of 1972, the Codetermination Law of 1976 for all corporations with more than 2000 employees, and the Civil Servants' Representation Law of 1955 in public administration; ${ }^{1}$

- the different regulations of Labor Law and the bulk of jurisdiction connected with the corresponding laws, especially the Labor Promotion Law (Arbeitsförderungsgesetz) of 1969, the Notice Protection Law (Kündigungsschutzgesetz) of 1969, and the Collective Agreement Law (Tarifvertragsgesetz) of 1949, revised 1969;

- collective agreements at sectoral, regional, and enterprise levels (such as the Frame Collective Agreements of 1973 in the metal industry of Nordwürttemberg-Nordbaden, or the regulations of wage agreements at the enterprise level, such as "Lodi" and "Lora" at Volkswagen).

There is, as we will see, a close interaction between these different elements of the German system of employee participation. As a first indication for this, one can look at specific forms of employee participation which cannot be strictly attributed to one of these forms, such as voluntary works agreements between management and works councils according to $\S 88$ of the 1972 Works Constitution Law, or the establishment of an arbitration committee (Schlichtungsstelle) instead of the legal agreement committee (Einigungsstelle) according to $\S 76$ of the Works Constitution Law.

These legal and contractual regulations do not exhaust the realm of employee participation; just like in many other industrialized countries one also finds a variety of informal. measures and agreements at almost every level of industrial relations. Hence, both the actual labor market situation and well-established but only informal rules of conduct and cooperation are to be considered as well. This is especially true of the lowest level of the individual employee and the single workplace, where informal interest articulation prevails and where the legal and contractual regulations only provide for some basic principles, such as the individual employee's right to information, complaint, and support by his representatives. Although some extensions of formal employee claims at the workplace level are conceivable, one has to add that this area is not completely and readily amenable to legal regulations.

\section{Limitations of Managerial Discretion by Means of Employee Participation in the Federal Republic?}

Especially if one concentrates on the legal provisions, one will easily arrive at the conclusion that these forms of participation are a clear restriction to managerial discretion, due to the fact that classical management prerogatives (such as the right to give 
orders, the rights of hiring, firing, and promoting, etc.) are subject to specific requirements, ranging from the obligation of the management to give information and justification for its particular measures, up to the need for common agreements with employee representatives (such as the works councils or the employee representatives in the supervisory board). This impression is even strengthened by the fact that all members of the managing board (including the one in charge of the personnel) are appointed by the "codetermined" Supervisory Board, and hence they are somehow dependent upon the latter for reasons of their re-appointment.

This comprehensible perception of employee participation as an "attenuation" of private property rights and of managerial prerogatives is shared by most critics of German employee participation (see e.g. Pejovich 1978) and by some of its proponents. Especially in the juridical literature on German industrial relations, this aspect is often (over-)emphasized, resulting in the theoretical derivation of harmful results of employee participation based on this underlying vision of participation as property rights attenuation. ${ }^{2}$ But from both theoretical and empirical grounds, some doubts have to be casted upon this narrow perception of the participation problem.

\section{Some Basic Theoretical Problems}

If we consider how employee participation by means of codetermination, collective bargaining, and labor law influences enterprise management, some basic questions often overlooked - have to be clarified beforehand:

(1) It is not justified on a priori grounds to define and evaluate the effects of employee participation only in terms of efficiency and productivity, although this is a very common procedure. It is not possible without prior value judgement to measure the performance and implications of employee participation solely in these terms. From the unions' and the workforce's perspective employee participation is an aim in itself; hence, it would be misleading to evaluate it solely in terms of possible efficiency gains. If we share the unionist view that in capitalist societies workers' preferences (for the quality of work, for autonomy, for creativity, etc.) are systematically underestimated, if not neglected, then we must admit that employee participation as a means for achieving wider goals, such as democratization in the sphere of production, increased influence on changes and adjustments of the work process, and an improved workers' position vis-à-vis the employers, has part of its remuneration in itself. Those broader goals can be evaluated so highly that possible efficiency losses might be tolerable up to a certain point as they are outweighed by the gains in terms of industrial democracy. To be sure, some potential feedbacks have to be taken into account, even if one accepts this position as, for instance, excessive efficiency losses, and resulting shortages, might well end up in reduced industrial democracy as well; the low degree of both participation and efficiency in the state socialist countries can be taken as a hint to this danger.

Admitting those possible negative feedbacks, however, does not mean that the idea of a certain trade-off between "efficiency" and "equality" is ruled out a priori. While it is 
without any doubt a value judgement to say that workers' interests have to be taken into account to a higher degree than the one effected via workers' exit option on the labor market, it is no less a normative position to narrow the analysis to the questions of efficiency, productivity, and managerial discretion. There are plausible arguments for confining the analysis to those questions, such as the large difficulties in measuring workers' "true" preferences and the practical need for participatory firms to be competitive with non-participatory ones (at least in international markets). Relevant as those questions are from a pragmatic viewpoint, they are nonetheless elements of a normative perception of the participation problem which cannot be justified on logical, but only on practical grounds.

(2) Connected with this unavoidable value judgement (for a broader or narrower demarcation of the participation issue), there is a second basic theoretical problem which is often overlooked by the critics of employee participation. Theoretical considerations concerning negative effects of employee participation are, as noted above, commonly based on the (implicit) assumption of attenuation of property rights and managerial discretion via legal and/or contractual restrictions in favor of the employees. This perception of the problem is incomplete in several respects:

Even if we look at the participation problem in the narrow sense of a redistribution of property rights, there is not only an attenuation (from the managers' and capital owners' viewpoint), but at the same time a strengthening of employees' property rights (for instance, in terms of better protection of their specific human capital and their seniority claims against depreciation by dismissal etc.). So, the question is not whether property rights are attenuated, but whose property rights are better specified and protected. Again, it does not go without a value judgement to decide whose claims should be given priority.

This normative implication has been seen very clearly by the German committee on codetermination chaired by Professor Biedenkopf (the so-called Biedenkopf Committee): the final recommendation for increased employee representation in the supervisory board - but short of full parity - was based on the Wertentscheidung ("normative decision") that enterprise policy should be primarily guided by rentability considerations, and that these considerations are best secured by giving capital owners and management the ultimate say (cf. Biedenkopf Report 1970, section V.B.II.2). So, the committee was well aware of the normative implications of their policy recommendations.

Before we come to the different attempts at evaluating the micro- and macro-economic consequences of employee participation in Germany (which, as we shall see, do not lend much support to the theoretically derived negative implications), a second issue namely the framework of these theoretical evaluations - has to be considered critically: roughly speaking, it is based on a comparison of an idealized situation with "full" property rights for capital owners and managers, and another situation where these rights are attenuated. In this narrow perspective it is all too easy to conclude that employee participation means the attenuation of property rights and hence a decrease in the value of all assets. However, a situation without employee participation is really 
not one with unrestricted property rights but rather a situation where other forms of labor market regulation, such as tedious collective bargaining, costly strikes and other forms of social conflict, frequent state intervention, or restrictive and rigid labor law prevail.

If one considers the interaction among different forms of coordination between "labor" and "capital", then this attenuation hypothesis cannot be easily maintained, and in this broader context it might well be the case that even in terms of profitability or managerial discretion the situation with some form of institutionalized employee participation might be a better one, given the fact that other forms of decision coordination in the labor market are not costless, and very often quite costly, to apply. Especially if one looks at employee participation in terms of exchange of information between the labor market parties, it is imaginable that participation may help to resolve prisoners' dilemma situations in which labor market parties otherwise would be trapped. ${ }^{3}$ Admitting incomplete and asymmetric information, different degrees of mobility for factor owners, especially the suppliers of labor power, it is not difficult to construct theoretical situations where employee participation - i.e. offering workers' "voice options" (Hirschman 1970) in addition to the only indirect interest articulation via "exit option" on the labor market - can be both a Pareto improvement and a situation which will not emerge out of the market process itself. ${ }^{4}$

To be sure, these theoretical deliberations do not show that there must be efficiency gains through institutionalized employee participation. However, they make clear that the implications of employee participation cannot be derived by pure theoretical reasoning, as in reality there is no comparison between two simple situations, one with full and the other with attenuated property rights, but between different situations which do not only imply distinct initial distributions of property rights among managers, capital owners, and employees but also a complex and dynamic interplay of different forms of decision coordination and interest articulation whose results cannot be derived a priori. Therefore, we will now turn to a short overview of available attempts at evaluating the German system of employee participation.

\section{Attempts at Empirical Evaluations of Employee Participation in West Germany}

The theoretical considerations of the preceding section were intended to make clear that even a restricted analysis of employee participation in terms of efficiency, profitability, and managerial discretion - omitting potential welfare gains due to improved regard to workers' interests - cannot be carried out by pure theoretical reasoning. As the German system of institutionalized employee participation, above all in the form of legal codetermination, has been the object of economic and social science research for more than 30 years, we should expect more or less reliable information about its impact on economic performance both at the enterprise and the economy level. However, the 
many empirical investigations fail to deliver clear, unambiguous, and, above all, general results. ${ }^{5}$

There are many possible reasons for the failure to detect clear negative (or positive) implications due to the restriction of managerial discretionary power in the German system of institutionalized employee participation. Without claim to completeness, the following reasons for this state of affairs vis-à-vis empirical results are discussed in the literature:

(1) Due to the fact that the ultimate power in economic affairs rests with capital owners and management ${ }^{6}$, the basic decisions are not really affected by the German system of employee participation; as the basic policy hence is not altered, also no basic differences in economic performance and behavior could be observed. This position is held by some leftist critics of German codetermination, such as Schauer (1973); but it is also shared, of course with a different normative evaluation, by the German Federal Constitutional Court (Bundesverfassungsgericht) in its March 1, 1979 decision on the constitutionality of the 1976 Codetermination Law, when the employers were nonsuited because the court recognized an ultimate say of management and shareholders and did not see clear indications for dysfunctional decision-making procedures under codetermination. ${ }^{7}$

(2) The existing empirical evaluations are unsatisfactory in many respects; most of them are case studies with very limited general applicability, the question of economic consequences of employee participation is by and large neglected, testable hypotheses have only been formulated infrequently, and even then modern econometric techniques have not been applied. The few econometric attempts at an evaluation, such as Svejnar's (1982a, b) or the study by Benelli et al. (1983), suffer, among other things, from the lack of appropriate data. ${ }^{8}$ What Monissen has said to the most extensive evaluation of codetermination up to now, the Biedenkopf Report, is a little bit too exaggerated but basically true for the bulk of empirical investigations in this field:

"A systematic quantitative assessment of the economic consequences of codetermination
was not attempted. Subjective criteria, a priori guesses, and idiosyncrasies replaced theoreti-
cal analysis, and a narrow documentation had to serve as a substitute for an appropriate
empirical implementation guided by the methodological standards of a developed social
science. Such an approach is symptomatic for the 'empirical' studies in the area of the
codetermination problem" (Monissen 1978: 77).

But this lack of appropriate techniques is ambivalent with respect to both positive and negative implications of employee participation: even if one shares Monissen's harsh evaluation of empirical research (and extends it to the more elaborate studies of the last ten years), he and other critics of empirical research fail to give clear indications why the use of more sophisticated techniques leads to the unambiguous negative results which they expect.

(3) Even those critics of codetermination, who were willing to accept the rather positive evaluation of its impact in the mining and steel and iron industry under the 1952 Codetermination Law, argue against general codetermination in big German corporations in the following way: as long as employee participation is restricted to special 
sectors and special categories of enterprises (such as big corporations in the Montan industry), competition with nonrestricted firms hinders the realization of the otherwise unavoidable negative consequences; so the detrimental effects of codetermination will become effective if it is generalized to all big companies. ${ }^{9}$ Against this kind of reasoning one could argue that international competition would hinder negative effects of codetermination in one single country; and if there was employee participation on a global level, then it would become almost impossible to measure negative consequences of employee participation, as they would be no longer a point of reference.

(4) A common argument in the German discussion of employee participation, which has also been raised by the Biedenkopf Committee (1970), sees also possible positive consequences of employee participation in terms of industrial relations, cooperation, frequency of strikes, and the like; in this view, the theoretically derived negative implications fail to materialize explicitly, as they are compensated by some positive aspects of employee participation. This line of thought comes close to our previous theoretical deliberations on the appropriate state of reference for employee participation: It is not the situation of complete and unattenuated property rights for capital owners and management, but of a different distribution and specification of property rights, combined with different kinds of interest articulation and decision coordination. For this reason, we shall go a little bit deeper into possible positive implications of institutionalized employee participation in the Federal Republic of Germany.

\section{Participation and Managerial Discretion in the Federal Republic of Germany}

As noted above, both the state and the results of empirical research into German codetermination are quite unsatisfactory. This is particularly true if one looks at possible positive implications of employee participation which may compensate for restricted managerial discretionary power. Nevertheless, there are some hints that the following relationships are of special importance:

(1) As the enterprise is defined by the unity of decision-making and decision implementing, the costs of participatory decision-making structures must not only be measured and evaluated in terms of the speed of decision-making, but also in terms of the efficiency of decision implementation: many empirical investigations indicate that legitimacy and social acceptability of entrepreneurial decisions are strenghtened, if the people concerned have some influence on the outcome of the decision-making process; hence, it is plausible to assume that there will be less frictions in the process of decision implementing in production as would be the case in a strictly hierarchical system (cf. Kirsch et al 1984, Scholl/Blumschein 1982, Witte 1981). Reasonable as this hypothesis might appear, it still needs further empirical investigation and evaluation, as the existing studies do not center around this question, and most of them are not carried out as longitudinal studies comparing the situation before and after codetermination has been 
introduced. Our own attempt at a comparative static evaluation (Diefenbacher et al. 1984) gives some indications for an increased legitimacy and acceptance of decisions subject to enterprise codetermination. However, improved employee representation in the supervisory board (which made the difference between the two points in time) was not strongly perceived by the working collective. This latter result conforms with most of the previous research projects in this field which found only minor rank and file interest and very deficient knowledge about codetermination at the enterprise level (in the supervisory board and through the labor director as a member of the board of directors). In spite of these more casual observations, there is no strong evidence for the hypothesis of increased legitimacy and acceptance, and hence further research is needed in order to test it.

(2) Another plausible hypothesis concerning positive implications of employee participation - sometimes formulated with respect to participatory systems, such as Yugoslavia (cf. Eames 1986) or with respect to participatory firms (cf. Hoppmann/Stötzel 1981) - focuses on the informational aspect: according to this hypothesis, employee participation may improve the outcome of the decision-making process itself, as important new aspects - otherwise overlooked by the management - can now enter the process of decision-making. This idea has not yet found much consideration in the empirical research on German employee participation, but it might be worthwhile to have a closer look at this relationship in future research. However, no extraordinary findings are to be expected, as the German system of employee participation centers on the ex post control of decision-making and not on the decision-making process itself.

(3) The economic recession during the last ten years in the Federal Republic of Germany - after 25 years of "economic miracle" - has changed somewhat the meaning of employee participation: during the earlier prosperous times, institutionalized participation was a means to distribute the gains and benefits of economic growth. But now in a recession period of more than ten years, institutionalized participation has to serve mainly the following two purposes:

- to defend workers' position as far as possible;

- to distribute the costs of economic adaptations.

The case of one big German electrotechnical corporation, AEG, shows quite clearly the shift in emphasis: employee representatives in the supervisory board were urged to approve of necessary adaptations implying job losses. So, attempts of implementing necessary adaptations to changed economic situations in a cooperative, less conflictridden way can be considered as the reverse side of the first hypothesis discussed above. While this kind of employee participation may increase managerial discretion in difficult times, it brings employee representatives into a rather difficult position: if they agree to the shut-down of plants and to dismissals, then they might get in conflict with rank and file workers; on the other hand, if they refuse to consent to those measures, they can be blamed by the management - with or without justification - for endangering the very survival of the enterprise.

(4) From a theoretical viewpoint, it is the relative immobility of workers which constitutes a participation problem: giving them some say in decisions which affect them 
directly, can be considered as a means to internalize the otherwise external costs of hierarchical decision-making. But at the same time, employee immobility leads to a certain uniformity of management and shareholder interests on the one hand, and the interests of the (immobile) working collective on the other: workers' interest in longterm employment is closely related to long-run efficiency and profitability of the enterprise. Hence, employee participation, especially if combined with some sort of profitsharing, is apt to increase employee motivation and efficiency (cf. FitzRoy/Kraft 1984). A common result of German research into codetermination (cf. Diefenbacher 1983) is the close correlation between the degree of involvement into participation and the time-horizon of the expected employment relationship: employees with long-run employment expectations (and hence rather high immobility) tend to be much more involved in the German system of employee representation than other categories of the workforce.

This fact in turn can increase managerial discretion for at least two reasons: first, workers' representatives are more interested in the long-run economic success of the enterprise than the "average worker", and, hence, they have more interests in common with the management. Second, they belong to the enterprise for an extended time period and hence are normally well-known to the management. Often they are able to establish informal and personal relationships among each other which may facilitate otherwise difficult agreements and compromises. This relatively high uniformity of interests, however, may pose a problem within the working collective, as more mobile and often less qualified - workers give higher weight to short-run returns, and hence they may not feel adequately represented by their representatives. As the wildcat strikes in the fall of 1969, e.g. at the Ford Automobile Plant in Cologne, have shown, there exist some conflicts within the workforce which may not only pose problems to employee representatives but to the management as well.

(5) Especially Kirsch et al. (1984) and Blumschein (1981) have investigated the influence of codetermination on the conditions of enterprise activity and found a positive influence of codetermination, due to the fact that employee participation increases workers' need satisfaction. They see a competitive relationship between works councils and the personnel division on how to serve best workers' needs, of course within the restrictions given by competitive requirements. Therefore, they consider codetermination as a promising possibility to reduce antagonistic elements in the enterprise and to strengthen the cooperative elements.

This is a very interesting finding: taken altogether, managerial discretion - even if it is subject to some procedures and rules due to codetermination - has in a way even increased, as there is more room for commonly accepted decision-making and action. This (suggested) relationship overlaps to some extent with the hypotheses (1) and (4) mentioned above. According to the studies by Kirsch et al., however, the main positive influence of codetermination is to be seen in the fact that effective institutionalized participation - especially through the works council - may lead to some form of competition between management and works council to serve workers' interests. It would be worthwhile to investigate how this competitive relationship will work under less 
favorable economic conditions. The question is then whether the enterprise's struggle for long-run survival might get in conflict with more short-run interests of parts of the working collective. In any case, the hypotheses by Kirsch et al. and their findings deserve more extended empirical research.

\section{Concluding Remarks}

As observed before, reliable empirical evaluation of employee participation in the Federal Republic of Germany is almost non-existent. This can be explained only partly by the technical deficits of available empirical studies. Whereas more reliable information can be obtained from further research and methodological improvements, there is one basic methodological problem which cannot be easily solved by empirical research. The problem which has to be taken into account whenever one attempts to measure the implications of institutionalized participation is the following one: whatever the merits and dangers of employee participation are, its influence on managerial discretion and enterprise behavior cannot be measured directly, as it is mediated by the way how management can cope with both the chances and limitations of institutionalized participation. So, the practical experiences of both management and employee representatives may vary considerably. This might help to explain why managerial evaluation of employee participation in West Germany seems to be rather ambivalent. The diverging subjective evaluations very heavily depend upon the specific situation in different branches and enterprises.

So, legal codetermination, collective bargaining, and labor law determine only a broad framework where interactions between representatives of both management and employees take place. It is difficult, if not impossible, to judge a priori whether more cooperative or more conflict-oriented patterns of interaction will evolve and persist; this will not only depend upon the individuals involved in this process, but also upon outside economic conditions.

I have noted at the beginning that it would be too superficial to consider employee participation per se as an attenuation of managers' and shareholders' rights. Of course, there is some redistributive element inherent in any form of institutionalized employee participation. At the same time there are also - both from theoretical and empirical grounds - potential gains involved in practical schemes. The redistributive element will be more pronounced if more centralized and more rigid rules - as they are often provided by labor law - prevail. From an economic viewpoint, those forms of employee participation are to be preferred which are more flexible and hence easier adaptable to changed economic conditions. In this perspective, agreements at decentralized levels (such as works agreements and enterprise agreements) are more apt to realize the potential gains of participation and to increase the room for managerial action. But one must also acknowledge the fact that those agreements can be facilitated by an appropriate legal framework within which both employers and employees can interact and 
develop reasonable patterns of interest articulation and coordination. So, legal regulations must not necessarily be considered as alternatives to preferable voluntary agreements, but they can be shaped as frame conditions which can help to facilitate them.

\section{Notes}

1 For a short overview of the major provisions and institutions of these codeterminations laws, see e.g. Nutzinger (1977; 1983, section I.2).

2 See, for instance, the (theoretical) analysis of suggested economic consequences of codetermination by Furubotn (1978) and by Prosi (1978) whose results are (theoretically) straightforward if one accepts the perception of codetermination as a mere attenuation of private property rights.

3 For instance, employee participation in the shaping of work conditions could help to avoid strikes against unsatisfactory conditions of work - while a strike could be very costly to both parties and very ineffective in terms of restructuring the work process.

4 For this, see the interesting contributions by Eger/Weise $(1984,1987)$.

5 For a good overview of the many empirical research projects see Diefenbacher (1983), especially chapter 5 to 8; for a short summary with further references see also Nutzinger (1983).

6 This is even true in the case of "full" Codetermination Law in the mining and steel and iron industry, as the management there can appeal (or threaten to appeal) to the general shareholders' meeting which can with a three-quarters majority of the votes overrule decisions made before by the (fully codeterminated) supervisory board - a fact which is often overlooked in the literature.

7 However, the Federal Constitutional Court added that the law would have to be revised if the practice of codetermination led to serious frictions and dysfunctionalities in decision-making; therefore, the Court implicitly assumed a kind of a managerial viewpoint, although it recognized at the same time legal protection of workers' rights.

8 These studies used industry data which are only very loosely related to the degree of codetermination and much closer connected with specific sectoral conditions; see also the critique by Kraft (1986).

9 A similar argument is made by Furubotn (1978: 155.)

\section{References}

Benelli, G./Loderer, C./Lys, Th. (1983): Labor Participation and Private Business Policymaking Decisions: The German Experience with Codetermination, Paper presented at the 10th Interlaken Conference on Analysis and Ideology.

Biedenkopf Report (1970): Mitbestimmung im Unternehmen, Stuttgart: Kohlhammer.

Blumschein, H. (1981): Personalpolitik, Personalplanung und Mitbestimmung: Eine empirische Untersuchung, München: Selbstverlag.

Diefenbacher, H. (1983): Empirische Mitbestimmungsforschung: Eine kritische Auseinandersetzung mit Methoden und Resultaten, Frankfurt/Main: Haag + Herchen.

Diefenbacher, H./Kißler, L./Nutzinger, H. G./Teichert, V. (1984): Mitbestimmung: Norm und Wirklichkeit, Fallstudie aus einem Großbetrieb der Automobilindustrie, Frankfurt/Main - New York: Campus.

Eames, A. (1986): Aspects of Economic and Managerial Development: European and African Experi- 
ences, Gramatzki, H. E. Betrieb und Partizipation in Osteuropa, Nutzinger, H. G. (Eds.), Frankfurt/ Main - New York: Campus.

Eger, T./Weise, P. (1984): Grundlagen einer ökonomischen Theorie der Partizipation. Diefenbacher, H./Nutzinger, H. G. (Eds.): Mitbestimmung: Theorie, Geschichte, Praxis, Heidelberg: Forschungsstätte der Evangelischen Studiengemeinschaft, 39-64.

Eger, T./Weise, P. (1987): "Die Evolution kapitalistischer und laboristischer Unternehmungen als Prozeß der Selbstorganisation”, FitzRoy, F./Kraft, K. (Hrsg.): Mitarbeiterbeteiligung und Mitbestimmung im Unternehmen, Berlin-New York: de Gruyter, 295-316.

FitzRoy, F. R./Kraft, K. (1984): Mitarbeiterbeteiligung und Produktivität. Eine ökonometrische Untersuchung, Zeitschrift für Betriebswirtschaft, 55: 20-35.

Furubotn, Eirik G. (1978): The Economic Consequences of Codetermination on the Rate and Sources of Private Investment. The Codetermination Movement in the West, Pejovich, S. (Ed.), Lexington, Mass.: D. C. Heath, 131-167.

Gramatzki, H. E./Nutzinger, H. G. (Eds.) (1986): Betrieb und Partizipation in Osteuropa, Frankfurt/ Main - New York: Campus.

Hirschman, A. O. (1970): Exit, Voice, and Loyalty: Responses to Decline in Firms, Organizations, and States, Cambridge, Mass.: Harvard University Press.

Hoppmann, K./Stötzel, B. (1981): Demokratie am Arbeitsplatz, Frankfurt/Main - New York: Campus.

Kirsch, W./Scholl, W./Paul, G. (1984): Mitbestimmung in der Unternehmenspraxis: Eine empirische Bestandsaufnahme, München: Selbstverlag.

Kraft, K. (1986): Empirical Studies on Codetermination: A Selective Survey and Research Design, in: Backhaus, J./Nutzinger, H. G. (Eds.): Codetermination, Berlin-Heidelberg-New York: Springer (forthcoming)

Muszynski, B. (1975): Wirtschaftliche Mitbestimmung zwischen Konflikt- und Harmoniekonzeptionen. Theoretische Voraussetzungen, geschichtliche Grundlagen und Hauptprobleme der Mitbestimmungsdiskussion der BRD, Meisenheim am Glan: Anton Hain.

Nutzinger, H. G. (1977): Co-Determination in the Federal Republic of Germany: Present State and Perspectives, Economic Analysis and Workers' Management, XI: 318-324.

Nutzinger, H. G. (1979): Uncertainty, Hierarchy, and Vertical Integration, Economic Analysis and Workers' Management, XIII: 301-326.

Nutzinger, H. G. (1983): Empirical Research into German Codetermination: Problems and Perspectives, Economic Analysis and Workers' Management, XVII: 361-382.

Pejovich, S. (Ed.) (1978): The Codetermination Movement in the West: Labor Participation in the Management of Business Firms, Lexington, Mass.: D. C. Heath.

Prosi, G. (1978): Volkswirtschaftliche Auswirkungen des Mitbestimmungsgesetzes 1976, Köln: Bachem.

Schauer, H. (1973): Critique of Co-Determination, in: Hunnius G./Garson, G. D./Case, J. (Eds.), Workers' Control: A Reader on Labor and Social Change, New York: Vintage Books, 210-224.

Scholl, W./Blumschein, H. (1982): Mitbestimmung und Bedürfnisbefriedigung der Arbeitnehmer, in: Nutzinger, H.G. (Ed.): Mitbestimmung und Arbeiterselbstverwaltung: Praxis und Programmatik, Frankfurt/Main-New York: Campus, 267-297.

Svejnar, J. (1982a): Employee Participation and Management, Bargaining Power, and Wages, European Economic Review, 18: 291-303.

Svejnar, J. (1982b): Codetermination and Productivity: Empirical Evidence from the Federal Republic of Germany, in: Jones D. C./Svejnar J. (Eds.): Participatory and Self-Managed Firms, Lexington, Mass.: D. C. Heath, 199-212.

Teuteberg, H.J. (1961): Geschichte der industriellen Mitbestimmung in Deutschland, Tübingen: J. C. B. Mohr.

Witte, E. (1981): Der Einfluß der Anteilseigner auf die Unternehmenspolitik, Zeitschrift für Betriebswirtschaft, 51: 733-779. 